\title{
The Effect of Fossil Fuel and Renewable Energy on Heat Requirement of Plastic and Polycarbonate Greenhouses
}

\author{
Nefise Yasemin Tezcan* \\ Akdeniz University, Faculty of Agriculture, Department of Agricultural Structures and Irrigation, 07070 \\ Antalya, Turkey \\ * Correspondence: nytezcan@akdeniz.edu.tr
}

\begin{abstract}
Greenhouse have to provide optimal climate conditions for healthy plant growth and high production. Heating of greenhouses is required for an efficient and reliable production specially during winter time in Turkey. However, even in the temperate zones, heating costs has a great portion in the total production costs. Coal is preferred as a fuel in the greenhouse heating in provinces of Turkey where there is no geothermal energy. In this study, the heating requirements and fuel cost (fossil and geothermal energy) for Antalya, Afyon, Kütahya, Denizli, and Aydın provinces in the Aegean and Mediterranean region have been identified based on long term meteorological data. The calculations were made for two model greenhouses located in an area with 1 ha representing modern greenhouses of the regions. The first is a gothic roofed plastic model greenhouse and the second is a gable roofed polycarbonate model greenhouse. According to the results of calculations, total annual heatingrequirement values ranged from 6,096,283 (for Antalya) to 20,359,946 MJ/ha (for Afyon) for the plastic greenhouse wheras these values ranged from 3,187,074 (for Antalya) to $10,643,972 \mathrm{MJ} / \mathrm{ha}$ (for Afyon) for the polycarbonate greenhouse.
\end{abstract}

Keywords: Polycarbonate; plastic; greenhouse; heating requirement; geothermal energy; Turkey

\section{Introduction}

Greenhouses are used in order to create a more favorable environment that is essential for plant growth and productivity. The growth factors (light, temperature, humidity and air composition) should be delivered and maintained at optimal levels [1]. Greenhouses must be heated in order to achieve these optimum conditions especially in cold seasons. Heating of a greenhouse is an essential requirement for proper growth and development of winter growing crops. However, heating costs have a large share (40\%-60\%) in total production expenditure, even in temperate climate regions [2,3]. Reducing this share will increase the operating profit in the greenhouse sector, which constitutes an important potential in agriculture, and will contribute greatly to the economy of the countries. Therefore, it is important to use renewable energy sources in greenhouses in order to minimize both greenhouse heating expenditures and the use of increasingly depleted fossil energy resources.

The world primary energy consumption is about $400 \mathrm{EJ} / \mathrm{year}$, mostly provided by fossil fuels $(80 \%)$. The renewables collectively provide $14 \%$ of the primary energy, in the form of traditional biomass $(10 \%)$, large $(>10 \mathrm{MW})$ hydropower stations $(2 \%)$, and the "new renewables" (2\%). Nuclear energy provides 6\% [4]. Turkey's primary-energy sources are hard coal, lignite, asphalt, bituminous schist, hydropower, oil, natural gas, geothermal and solar energy, wood, as well as animal and plant wastes. Although Turkey has energy resources, these are limited. More than half (52\%) of the net energy consumption in the country is met by imports, and the share of imports continues to increase each year. However, the level of energy production in Turkey is very low [5]. Coal is a major fuel source for Turkey, used primarily for power generation, steel manufacturing, cement production, and greenhouse heating. Turkish coal consumption has remained roughly stable over the past decade and currently accounts for about $24 \%$ of the country's total energy consumption [6,7]. On the other hand, Turkey has very limited oil and natural gas resources. Because the 
consumption of oil and natural gas is significantly higher than the reserves, the import of these two energy inputs is increasing year by year. Turkey has substantial reserves of renewable energy resources. These resources represented about $12.7 \%$ of total primary energy consumption. Renewable resources are the second-largest domestic energy source after coal. In Turkey, main renewable energy resources are hydro, biomass, wind, geothermal, and solar [8]. Turkey is the seventh richest country in the world in geothermal energy potential [9]. The overall geothermal potential of Turkey is about 38,000 MW. Around $88 \%$ of this potential is appropriate for thermal use (low enthalpy fields with temperature less than $200{ }^{\circ} \mathrm{C}$ ) and the remainder for electricity production (high enthalpy fields with temperature more than $200{ }^{\circ} \mathrm{C}$ ). Only $7.2 \%$ of the low enthalpy fields and $4.4 \%$ of the high enthalpy fields are proven, and the remainder is probable and possible reserve [10]. The main uses of geothermal energy are space heating and domestic hot water supply, greenhouse heating, industrial processes, heat pumps and electricity generation [9]. Most of the development has been in district heating, which now serves 103,000 residences (827 MWt and 7712.7 TJ/year), and in individual space heating (74 MWt and $816.8 \mathrm{TJ} /$ year). A total of $800,000 \mathrm{~m}^{2}$ of greenhouses are heated by geothermal fluids (192 MWt and $3633 \mathrm{TJ} /$ year). Geothermally heated pools used for bathing and swimming account for a capacity of $402 \mathrm{MWt}$ and utilize 12,677.4 TJ/year. Geothermal heat is used in 54 combined space heating and spa installations, and at 215 balneological facilities. About 120,000 tonnes of liquid carbon dioxide and dry ice are produced annually at the Kizildere power plant [11].

Sustainability of greenhouses can be achieved by increasing energy efficiency. However, the improvement of energy efficiency is possible by using renewable energy sources that don't produce waste instead of using fossil energy resources that contribute to global warming by increasing the greenhouse effect [12]. Clean, domestic, and renewable energy is commonly accepted as the key for future life, not only for Turkey but also for the world [10]. When heating is done in modern greenhouses to be established in the regions where geothermal resources are available, high quality high efficiency can be achieved all year [12].

Gourdo et al. [13] have studied a solar energy storing rock-bed system to heat the ambient air inside a canarian type greenhouse. The results showed that the rock-bed system increased the greenhouse air temperature during the night by $3{ }^{\circ} \mathrm{C}$ compared to the conventional greenhouse, and $4.7^{\circ} \mathrm{C}$ compared to the outside. Hassanien et al. [14] analyzed the integration of an evacuated tube solar collector (ETC) with an electric heat pump for greenhouse heating in Kunming, China. It was concluded that the ETC could increase the internal air temperature in the heated greenhouse by $2{ }^{\circ} \mathrm{C}-3{ }^{\circ} \mathrm{C}$ and decrease the relative humidity by $10 \%$ compared to the unheated and provide more than $35 \%$ of the annual required heat for heating the greenhouse and maintain the nocturnal temperature at $14^{\circ} \mathrm{C}$ inside the greenhouse. Bazgaou et al. [15] investigated the thermal performance of a rock-bed heating active systems to heat a canarian greenhouse during winter period in order to improve the climatic conditions and to increase the production. This heating system improved the greenhouse microclimate during the nocturnal and winter periods with an increase of the inside air temperature of the greenhouse by $2.6{ }^{\circ} \mathrm{C}$ and reduction of its relative humidity by $10 \%$. This improvement had a very positive impact on plants development and tomato yield which is improved by $29 \%$. Canakci et al. [7] reported the heating requirements of the greenhouses in a Mediterranean basin by using monthly average meteorological data. The calculation of the annual heating requirement for plastic model greenhouse (approximately 1 ha) and coal heated in Turkey was between 3,592,848 and 10,459,688 MJ/ha and coal costs were between 37,412 and 108,916 \$/ha. Kasap and Erdem [16] realized a study to compare different heating systems with a geothermal one in Tokat Province, Turkey. It was concluded 
that the heating system powered by geothermal energy was more economical in both glass and plastic houses.

Located in the Mediterranean countries zone, Turkey is a prominent center of greenhouse cultivation. The Mediterranean, Aegean and Marmara regions are the areas where greenhouse cultivation is common in Turkey. About $87 \%$ of the greenhouse production area in Turkey is concentrated in the Mediterranean region [17]. The majority of the greenhouses in the Mediterranean region are located in city of Antalya. In recent years, greenhouse cultivation has started to develop in the internal regions (such as Denizli, Aydin, Manisa, İzmir, Kütahya, Afyon, Balıkesir and Urfa) with the use of geothermal energy from alternative energy sources. According to statistics of 2018, the total greenhouse area in Turkey is 44,700 ha of which 7800 ha is covered glass and 36,900 ha covered plastic. Today, the annual export value of greenhouse vegetables has reached 453 million $\$[18,19,20,21,22]$.

Greenhouse vegetable production in the Turkey is performed widely in the farmer greenhouses by traditional methods. Due to the high costs of fossil fuels used in greenhouse heating, the heating operation is done only to protect plants from frost hazards and the traditional wood stoves are used fuel for this purpose $[23,24]$. However, adequate levels of the heating process affect the production quality and can increase yield by $50-60 \%$. The geothermal energy is more economical to provide the necessary temperature values for plant development in greenhouses. In addition, the humidity inside the greenhouse is kept under control and thus the spread of disease can be prevented [25]. In Turkey, the production in farmer greenhouses can be done as single crop cultivation per year as well as double crop cultivation in autumn and spring periods. Depending on the production period, an average yield of $150,000 \mathrm{~kg} / \mathrm{ha}$ (tomato) can be taken from these greenhouses. On the other hand, changes consumer demand and enviromentally conscious manufacturing have brought up food production tecniques highlighting the food security and related certification processes (Good Agricultural Practice-GAP). Therefore, after 2000s, climate-controlled modern greenhouse aplications obtaining higher quality products and food security has been widespread applications [23,26]. Modern greenhouse is an industrial application that combines technologies from different disciplines such as agriculture, biosystem, construction, machinery, electrical-electronics and computer engineering [27]. According to the data of the year 2010, a total area of modern greenhouses is 391.2 ha of which 227.0 ha is located in Antalya province. In recent years, greenhouses have been developing rapidly in our internal regions thanks to the cheap heating provided by geothermal energy. Production in modern greenhouses is applied usually as single crop cultivation per year (commonly tomato). The yield in these greenhouses varies between $350,000-450,000 \mathrm{~kg} / \mathrm{ha}$. When greenhouse indoor conditions are better achieved, this yield increases to even higher values. For example, suitable temperature values can not be provided for plant requests due to the heating costs in modern greenhouses on the Antalya coastline at cold nights. Accordingly, the yield is observed decline in greenhouses. Thus, it can be said that the heating of modern greenhouses with geothermal energy is cost-effective compared to fossil fuels and this situation affects the efficiency of production.

Heating costs are one of the most important factors affecting the profitability of the greenhouse in the temperate climate zone (Mediterranean coastline, Italy, Spain, Turkey etc.). In these countries, greenhouse cultivation is carried out depending on ecological conditions. As the heating costs by conventional energy sources (coal, oil, and natural gas) is too high, the use of renewable energy technologies and systems to heat the greenhouses have gained much attention in recent years. In this research, the heating requirements and costs (coal and geothermal energy heated) for a model modern plastic and polycarbonate greenhouse were determined by considering the meteorological data for five provinces located in the Mediterranean and Aegean region in Turkey. 


\section{Materials and Methods}

\subsection{Research region}

Turkey is situated on the Alpine-Himalayan orogenic belt and the Miocene or younger grabens are developed as the result of this orogeny. Wide spread volcanism, fumarole hydrothermal alterations and the existence of more than 600 hot springs, some of which have $100^{\circ} \mathrm{C}$ and greater temperatures, indicate that Turkey has an important geothermal energy potential [10]. Geothermal fields in Turkey are concentrated mostly in the Marmara, Aegean and inner western parts of Anatolia [28]. The most important region within these regions for geothermal potential is Aegean region, covering almost 78\% of total geothermal fields [29]. Aegean region has a rich potential in terms of geothermal energy and takes first place in geothermal greenhouse [24].

Geothermal systems in Western Anatolia have generally high temperatures and take place in grabens due to opening tectonics. Geothermal fields in this region are among the high temperature fields, such as Denizli-Kızıldere geothermal field $\left(242{ }^{\circ} \mathrm{C}\right)$, Aydın-Germencik geothermal field $\left(232{ }^{\circ} \mathrm{C}\right)$, Aydın-Salavatlı geothermal field $\left(171{ }^{\circ} \mathrm{C}\right)$, Aydın-Yılmazköyİmamköy geothermal field $\left(142^{\circ} \mathrm{C}\right)$, Manisa-Salihli Caferbeyli field $\left(155^{\circ} \mathrm{C}\right)$, Manisa-SalihliKurşunlu field $\left(96^{\circ} \mathrm{C}\right)$, Manisa-Alaşehir-Kavaklıdere field $\left(116^{\circ} \mathrm{C}\right)$, Manisa-Turgutlu-Urganlı field $\left(86^{\circ} \mathrm{C}\right)$, Kütahya-Simav geothermal field $\left(162{ }^{\circ} \mathrm{C}\right)$, Kütahya-Gediz-Abide geothermal field ( $\left.97^{\circ} \mathrm{C}\right)$, İzmir-Seferihisar field $\left(153^{\circ} \mathrm{C}\right)$, İzmir-Balcova field $\left(130^{\circ} \mathrm{C}\right)$, İzmir-Dikili field $\left(130{ }^{\circ} \mathrm{C}\right)$, and İzmir-Aliağa field $\left(96^{\circ} \mathrm{C}\right)$. There are also low and middle enthalpy geothermal fields in Afyonkarahisar, Manisa, Pamukkale and İzmir provinces. Afyonkarahisar, Manisa, Pamukkale and İzmir provinces have also low and medium enthalpy geothermal fields.

Heating of greenhouses using geothermal fluids has become very popular in Turkey in recent years. Most of these greenhouses are in Western Anatolia. The ones in operation cover more than 13 ha and some 6 ha of new greenhouses are in the planning stage and may be built in the near future. The greenhouses are geothermally heated between 1500 and $2000 \mathrm{~h}$ per year; tomatoes and peppers (California Wonders) are the main crops [30]. According to statistics of 2015, total greenhouse area by using geothermal resources in Turkey is 3858.9 acres in 15 provinces. The majority of the greenhouses in these provinces are located in İzmir (21.2\%), Manisa (16.2\%), Afyonkarahisar (15.8\%) and Denizli (13.3\%) [31].

Geographic location of research area is shown in Figure 1. Except for the province of Antalya, other selected provinces are geothermal resources. 


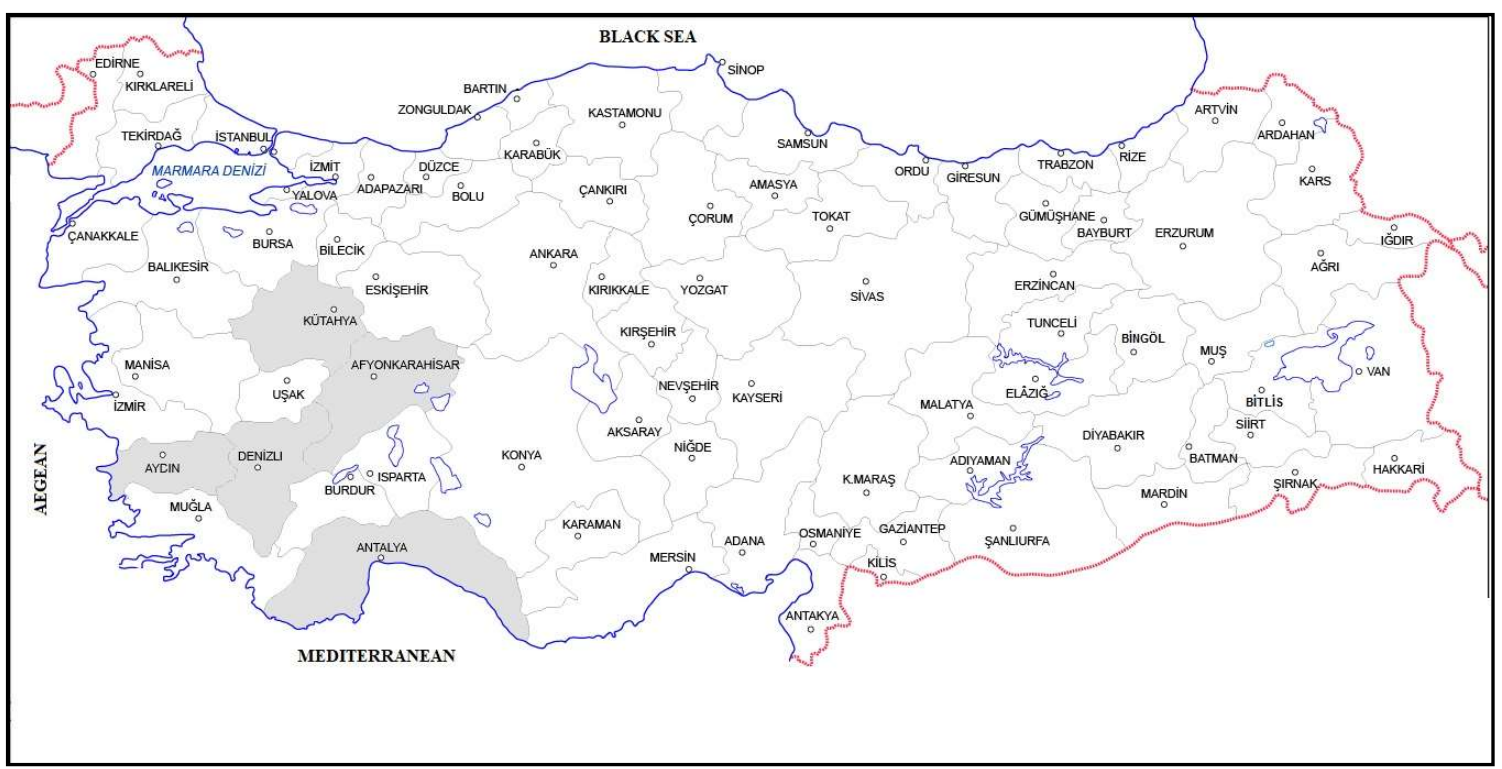

Figure 1. Locations of study areas.

Protected cultivation areas of the selected provinces and also of Turkey's total are given in Table 1. As seen in this table, the majority of the greenhouses in the Turkey are located in city of Antalya [20,22]. In the selected regions, greenhouse farming generally starts in the months of August or September depends on the crop and the method of growing continues until the end of June [7].

Table 1. Protected cultivation area in Aegean and Mediterranean Region in Turkey.

\begin{tabular}{ccccccc}
\multirow{2}{*}{ Province } & \multicolumn{2}{c}{ Glasshouse } & \multicolumn{2}{c}{ Plastichouse } & \multicolumn{2}{c}{ Total area } \\
\cline { 2 - 7 } & ha & $\%$ & ha & $\%$ & ha & $\%$ \\
\hline Antalya & 6358.4 & 81.4 & $19,344.3$ & 52.5 & $25,702.8$ & 57.5 \\
Afyon & 9,5 & 0.1 & 101.4 & 0.3 & 110.9 & 0.2 \\
Aydin & 14.2 & 0,2 & 90.3 & 0.2 & 104.5 & 0.2 \\
Denizli & 0.6 & - & 138.6 & 0.4 & 139.2 & 0.4 \\
Kütahya & 0.5 & - & 46.6 & 0.1 & 47.1 & 0,1 \\
\hline Total & 6383.2 & 81.7 & $19,721.1$ & 53.5 & $26,104.5$ & 58.4 \\
\hline Others & 1427.8 & 18.3 & $17,131.6$ & 46.5 & $18,559.4$ & 41.6 \\
\hline Turkey & 7811.0 & 100.0 & $36,852.7$ & 100.0 & $44,663.9$ & 100.0 \\
\hline
\end{tabular}

Climate data on average, maximum and minimum temperatures, solar radiation intensity and and sun exposure duration were gathered from long-term averages of the selected regions recorded by General Directorate of Meteorology [32]. Climate data for study area were given in Table 2 and Figure 2. 


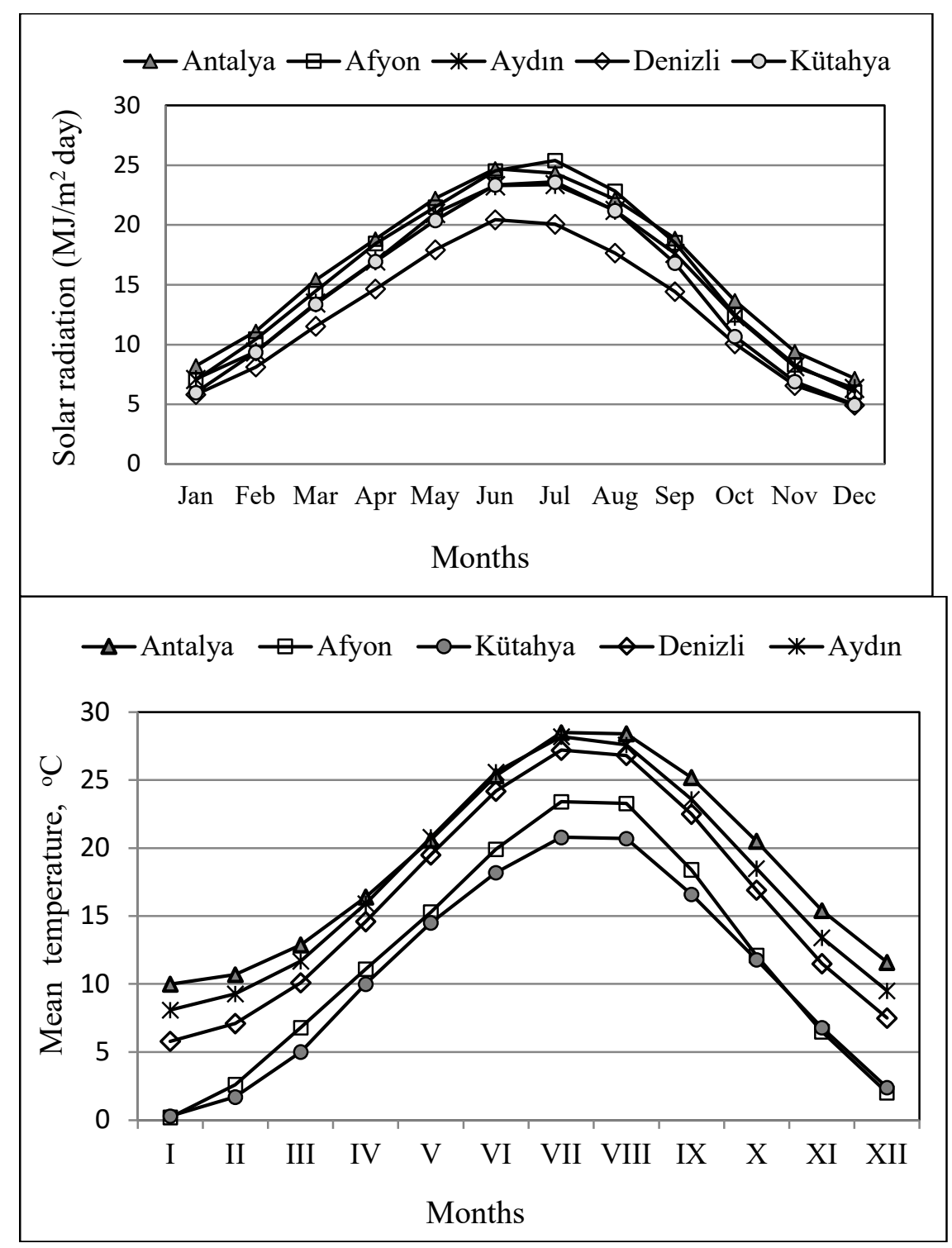

Figure 2. Mean temperature values and solar radiation values for the selected provinces (1929-2018).

Table 2. Some climate data for long-term averages of selected provinces (1929-2018).

\begin{tabular}{ccccc} 
Province & $\begin{array}{c}\text { Mean } \\
\text { temperature } \\
\left({ }^{\circ} \mathrm{C}\right)\end{array}$ & $\begin{array}{c}\text { Mean high } \\
\text { temperature } \\
\left({ }^{\circ} \mathrm{C}\right)\end{array}$ & $\begin{array}{c}\text { Mean Low } \\
\text { temperature }\end{array}$ & $\begin{array}{c}\text { Daily } \\
\text { shiny }\end{array}$ \\
\hline Antalya & 18.8 & 35.7 & 4.2 & $(\mathrm{~h})$ \\
Afyon & 11.8 & 29.3 & -8.1 & 6.4 \\
Aydın & 17.7 & 35.8 & 1.3 & 7.0 \\
Denizli & 16.1 & 34.8 & -0.4 & 7.4 \\
Kütahya & 10.7 & 30.1 & -10.7 & 6.0 \\
\hline
\end{tabular}




\subsection{Model greenhouses}

In this study, considering the conditions of the region and farm properties a typical plastic greenhouse and polycarbonate greenhouse has been identified and used as material.

Plastic greenhouse: The geometrical characteristics of this greenhouse are as follows: side height of $4.5 \mathrm{~m}$; ridge height of $6.5 \mathrm{~m}$, width of $9.6 \mathrm{~m}$, length of $104.2 \mathrm{~m}, 10$ tunnels. The frame of the greenhouse was made of steel. The model greenhouse has gothic roof, total area of $10,003 \mathrm{~m}^{2}$, cover surface area of $13,055 \mathrm{~m}^{2}$. Its covering material is single-layer polyethylene film [7].

Polycarbonate (PC) greenhouse: The geometrical characteristics of PC greenhouse are as follows: side height of $4.5 \mathrm{~m}$; ridge height of $7.5 \mathrm{~m}$, width of $12.0 \mathrm{~m}$, length of $104.2 \mathrm{~m}, 8$ tunnels. The frame of the greenhouse was made of steel. The model greenhouse has saddle roof, total area of $10,003 \mathrm{~m}^{2}$, cover surface area of $13,260 \mathrm{~m}^{2}$. Its covering material is doublelayer PC film.

\subsection{Calculations}

Heat and fuel requirements of the model greenhouse were calculated in this study. The desired amount of heat requirements to ensure the ambient inside temperature of the greenhouse was calculated with the help of following equation:

$$
\mathrm{Q}=\mathrm{Q}_{\mathrm{K}}-\mathrm{Q}_{\mathrm{G}}
$$

where, $\mathrm{Q}$ is the total heat requirement $(\mathrm{W}), \mathrm{Q}_{\mathrm{K}}$ is the amount of heat loss from the greenhouse $(\mathrm{W}), \mathrm{Q}_{\mathrm{G}}$ is the amount of incoming solar radiation inside the greenhouse (W).

The amount of incoming solar radiation can be determined with the following equation:

$$
\mathrm{Q}_{\mathrm{G}}=\mathrm{I}_{\mathrm{o}} \times \mathrm{A}_{\mathrm{r}} \times \eta_{\mathrm{s}}
$$

where, $I_{o}$ is the average daily solar radiation intensity $\left(\mathrm{W} / \mathrm{m}^{2}\right), A_{r}$ is the roof area $\left(\mathrm{m}^{2}\right), \eta_{\mathrm{s}}$ is the conversion ratio of solar energy to beneficial energy for greenhouse heating during the day (decimal) and this value is accepted as 0.5 [33,34].

The values related to temperature, solar radiation intensity and sun exposure duration obtained from the records of the State Meteorology Affairs General Directorate were taken as the average of years in the study. Calculations were made by taking into account the average temperature values at night time and daytime depending on the sun exposure.

The amount of heat energy lost from the greenhouse was calculated with the help of following equation $[21,33,35]$ :

$$
Q_{K}=\Sigma A_{o} U\left(T_{i}-T_{d}\right)
$$

where, $\Sigma A_{o}$ is total cover surface area $\left(\mathrm{m}^{2}\right), U$ is overall heat transfer coefficient $\left(\mathrm{W} / \mathrm{m}^{20} \mathrm{~K}\right), \mathrm{T}_{\mathrm{i}}$ is greenhouse internal ambient temperature $\left({ }^{\circ} \mathrm{C}\right), \mathrm{T}_{\mathrm{d}}$ is greenhouse outdoor temperature $\left({ }^{\circ} \mathrm{C}\right)$. The night and day ambient temperatures for the model greenhouse in the calculations was taken $16{ }^{\circ} \mathrm{C}$ and $21{ }^{\circ} \mathrm{C}$ which are accepted as the favorable inside temperature (ti) in greenhouse vegetable growing [2]. The total value related to coefficient $(U)$ of heat transmission in the greenhouse depends on various factors such as the size of the greenhouse, the type of the cover material and heaters, and wind speed. Therefore, it is reported that it is not possible to determine the heat transfer coefficient completely and accurately under the application conditions, so, the coefficient values determined and proposed based on experience rather than detailed calculations were used for the application processes. In the calculations, the total heat transfer coefficient for the plastic and PC greenhouse was taken as a value of $6.8 \mathrm{~W} / \mathrm{m}^{2} \mathrm{~K}$ and $3.5 \mathrm{~W} / \mathrm{m}^{2} \mathrm{~K}$, respectively $[33,36,37]$. 
Monthly heating requirement value (W/ha) was determined by take into consideration the values of heat loss $\left(\mathrm{Q}_{\mathrm{k}}\right)$. The value was calculated with the help of following equation [35]. Also, annual heating requirement of the greenhouses can be found by collecting of the monthly values. Considering the calculations, it has beenidentified that heating is not necessary during the daytime since the average solar radiation meets the heat loss of the greenhouse. Therefore, heating calculations were done for the night time inwhich there is no solar radiation $[7,19]$.

$$
\Sigma \mathrm{Q}_{\mathrm{m}}=\Sigma \mathrm{A}_{\mathrm{o}} \times \mathrm{U} \times\left(\mathrm{t}_{\mathrm{i}}-\mathrm{t}_{\mathrm{d}}\right) \times 3.6 \times \mathrm{HH}_{\mathrm{d}} \times \mathrm{DN}_{\mathrm{m}}
$$

where, $\Sigma \mathrm{Q}_{\mathrm{m}}$ is monthly heating requirement $(\mathrm{kj}), \mathrm{HH}_{\mathrm{d}}$ is daily heating hour (h/day) and $\mathrm{DN}_{\mathrm{m}}$ is number of day per month (day/month).

Fuel (coal) requirement per month was determined with the help of the following equation [37]:

$$
C R_{m}=\frac{\Sigma Q_{m}}{L H V \times \eta}
$$

where, $\mathrm{CR}_{\mathrm{m}}$ is the monthly coal requirement $(\mathrm{kg})$, LHV is the low heat energy value of coal $(\mathrm{kJ} / \mathrm{kg}), \eta$ is the efficiency of the heating system. The low heat energy value of coal and the efficiency of the heating system were considered as $28,010 \mathrm{kj} / \mathrm{kg}$ and $80 \%$, respectively [38]. In addition, the price of fuel per unit was regarded $\$ 310 /$ ton and fuel costs were calculated with the help of the following equation:

$$
\mathrm{CC}_{\mathrm{m}}=\mathrm{CR}_{\mathrm{m}} \times \mathrm{CP}
$$

where, $\mathrm{CC}_{\mathrm{m}}$ is the coal cost per month (\$/month), $\mathrm{CP}$ is coal price per unit $(\$ / \mathrm{kg})$.

The required water flow for heating systems in the greenhouses that use geothermal energy can be determined by the following equation:

$$
\mathrm{FFR}_{\mathrm{m}}=\frac{\Sigma Q_{m}}{\rho \times C_{p} \times \Delta T \times \eta} \times 3600
$$

where, FFR $\mathrm{m}_{\mathrm{m}}$ is the fluid flow rate for greenhouse heating system $\left(\mathrm{m}^{3} / \mathrm{h}\right), \rho$ is the density of water $\left(\mathrm{kg} / \mathrm{m}^{3}\right)\left(977.52 \mathrm{~kg} / \mathrm{m}^{3}\right), \mathrm{C}_{\mathrm{p}}$ is the specific heat of water $\left(\mathrm{kj} / \mathrm{kg}{ }^{\circ} \mathrm{C}\right)\left(4.191 \mathrm{kj} / \mathrm{kg}{ }^{\circ} \mathrm{C}\right), \Delta \mathrm{T}$ is is the average of the temperatures of the water exiting from and returning the furnace $\left({ }^{\circ} \mathrm{C}\right)$ and $\eta$ is the efficiency of the exchanger. In this study, the efficiency of the exchanger was considered as $85 \%$ [34]. It was also considered that temperature of the water coming out of the furnace was $80{ }^{\circ} \mathrm{C}$ and that of returning water was $60{ }^{\circ} \mathrm{C}$ in the calculations. In addition, the price of fluid flow per unit was regarded $\$ 0.18 / \mathrm{m}^{3}$ and fluid flow costs were calculated with the help of the following equation:

$$
\mathrm{FFC}_{\mathrm{m}}=\mathrm{FFR}_{\mathrm{m}} \times \mathrm{FFP}
$$

where, $\mathrm{FFC}_{\mathrm{m}}$ is the fluid flow cost per month (\$/month), FFP is fluid flow price per unit $\left(\$ / \mathrm{m}^{3}\right)$.

\section{Results}

\subsection{Heat operation}

Average night temperature values in the research area during a year were given in Figure 3. Also, the value of $16{ }^{\circ} \mathrm{C}$ is accepted as the favorable inside temperature $\left(t_{i}\right)$ in greenhouse vegetable growing was shown in the Figure 3. 


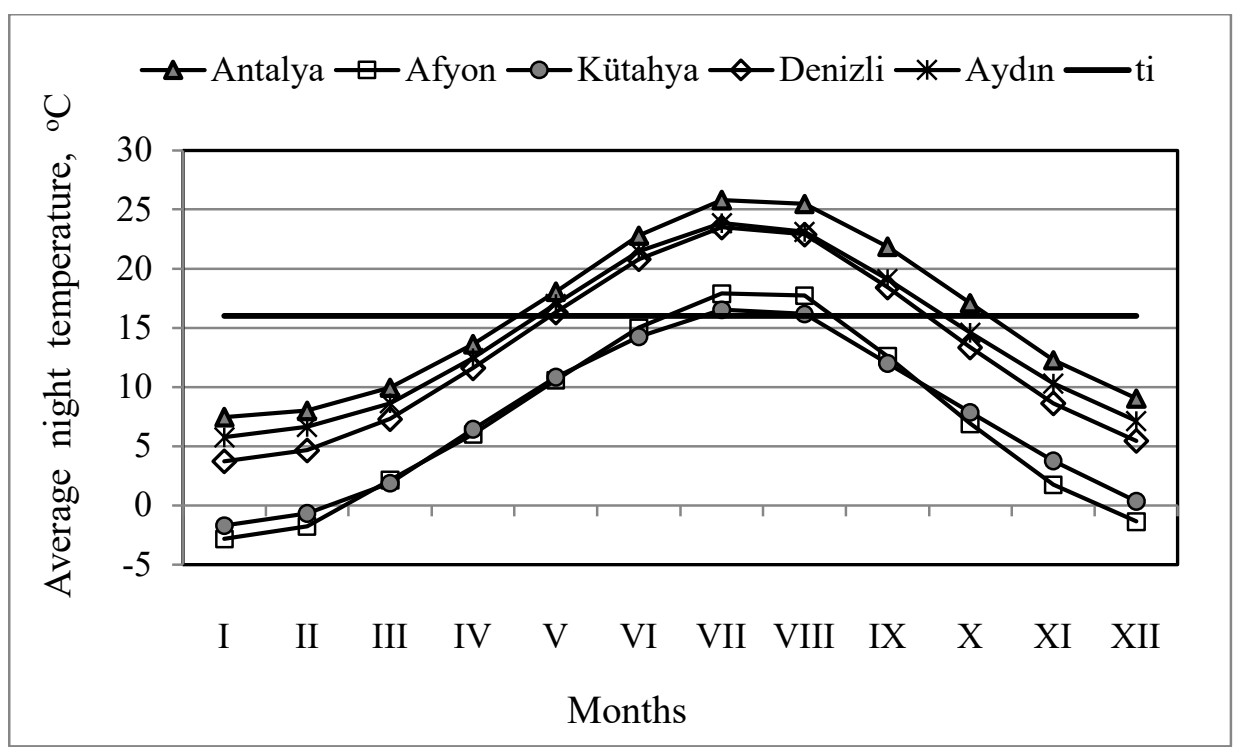

Figure 3. Average night temperature values for the selected provinces.

As seen in this figure, heating operations should be realized for the section below the straight line of $16^{\circ} \mathrm{C}$. For this reason, heating operation needs to be done in the period between November and April in the province of Antalya, October and April in the province of Denizli and Aydın when this operation needs to be done in the period between September and June in Afyon and Kütahya provinces. The highest night temperature values occur in the province of Antalya. The period required for the heating operation depends on both the temperature and the length of the solar radiation time. Total monthly heating time (hour) calculated for the operations in the specified period are given in Table 3.

Table 3. The average monthly heating time (h/month) for the selected provinces.

\begin{tabular}{cccccc}
\hline Months & Antalya & Afyon & Aydın & Denizli & Kütahya \\
\hline Sep & - & 532.2 & - & - & 578.7 \\
Oct & - & 560.0 & 516.7 & 516.7 & 600.0 \\
Nov & 510.0 & 640.7 & 565.0 & 570.0 & 671.7 \\
Dec & 589.0 & 651.0 & 609.7 & 625.2 & 661.3 \\
Jan & 578.7 & 555.3 & 614.8 & 614.8 & 569.3 \\
Feb & 490.0 & 578.7 & 536.7 & 536.7 & 589.0 \\
Mar & 511.5 & 515.0 & 552.8 & 558.0 & 530.0 \\
Apr & 475.0 & 485.7 & 510.0 & 510.0 & 496.0 \\
May & - & 420.0 & - & - & 430.0 \\
Jun & - & 440.0 & - & - & 475.0 \\
\hline Total (h/year) & 3154.2 & 5378.5 & 3905.7 & 3931.3 & 5601.0 \\
\hline
\end{tabular}

According to Table 3, the shortest heating period is required for the province of Antalya $(3154,2 \mathrm{~h} /$ year) and the longest for Kütahya province $(5601,0 \mathrm{~h} /$ year). It can be said that Afyon and Kütahya provinces have low night temperature values (Figure 3) and so needs heating operations three or four months more than the others (Denizli, Aydın, Antalya). High average night temperature values and long solar radiation time caused lower values in Antalya than the other provinces.

\subsection{Heat requirement}


Total monthly heat requirements $(\mathrm{MJ} / \mathrm{ha})$ calculated for plastic and polycarbonate greenhouses are given in Table 4 and in Table 5.

Table 4. The values of the heat requirement (MJ/ha per month) for plastic greenhouse.

\begin{tabular}{cccccc}
\hline Months & Antalya & Afyon & Aydin & Denizli & Kütahya \\
\hline Sep & - & 478,101 & - & - & 607,214 \\
Oct & - & $1,547,666$ & 231,167 & 434,815 & $1,504,130$ \\
Nov & 608,493 & $2,547,317$ & $1,023,209$ & $1,341,943$ & $2,345,764$ \\
Dec & $1,311,380$ & $3,555,796$ & $1,727,592$ & $2,104,505$ & $3,355,781$ \\
Jan & $1,578,103$ & $3,911,354$ & $2,010,772$ & $2,410,306$ & $3,740,951$ \\
Feb & $1,252,779$ & $3,153,174$ & $1,600,773$ & $1,943,796$ & $3,032,520$ \\
Mar & 986,260 & $2,558,254$ & $1,301,528$ & $1,551,464$ & $2,654,133$ \\
Apr & 359,268 & $1,640,384$ & 581,328 & 717,152 & $1,614,764$ \\
May & - & 838,147 & - & - & 813,710 \\
June & - & 129,752 & - & - & 238,198 \\
\hline Total & $6,096,283$ & $20,359,946$ & $8,476,369$ & $10,503,981$ & $19,907,165$ \\
\hline \multicolumn{7}{c}{}
\end{tabular}

Table 5. The values of the heat requirement (MJ/ha per month) for polycarbonate greenhouse.

\begin{tabular}{cccccc} 
Months & Antalya & Afyon & Aydın & Denizli & Kütahya \\
\hline Sep & - & 249,946 & - & - & 317,445 \\
Oct & - & 809,104 & 120,852 & 227,317 & 786,344 \\
Nov & 318,114 & $1,331,711$ & 534,923 & 701,554 & $1,226,342$ \\
Dec & 685,576 & $1,858,934$ & 903,167 & $1,100,214$ & $1,754,368$ \\
Jan & 825,016 & $2,044,816$ & $1,051,211$ & $1,260,084$ & $1,955,731$ \\
Feb & 654,940 & $1,648,447$ & 836,868 & $1,016,196$ & $1,585,370$ \\
Mar & 515,606 & $1,337,429$ & 680,426 & 811,090 & $1,387,554$ \\
Apr & 187,822 & 857,576 & 303,912 & 374,920 & 844,182 \\
May & - & 438,175 & - & - & 425,399 \\
June & - & 67,833 & - & - & 124,528 \\
\hline Total & $3,187,074$ & $10,643,972$ & $4,431,359$ & $5,491,374$ & $10,407,262$ \\
\hline
\end{tabular}

As seen in these tables, plastic greenhouse has the highest annual heating requirements, whereas polycarbonate greenhouse has the lowest annual heating requirements in all provinces in specified periods. The annual heating requirement ranged from 6,096,283 (for Antalya) to 20,359,946 MJ/ha (for Afyon) for the plastic greenhouse (Table 4). Similar results were also reported by other researchers [7,39].

The annual heating requirement ranged from 3,187,074 (for Antalya) to 10,643,972 MJ/ha (for Afyon) for the polycarbonate greenhouse (Table 5). It can be said that the polycarbonate greenhouse reduces heat requirement by $47.7 \%$. January was determined as the month in which the heating requirements for two model greenhouses was the highest. This value ranged from 1,578,103 (for Antalya) to 3,911,354 (for Afyon) MJ/ha and from 825,016 (for Antalya) to $2,044,816$ (for Afyon) $\mathrm{MJ} /$ ha for plastic and polycarbonate greenhouses, respectively. 


\subsection{Fuel requirement and costs}

Coal is widely used as a fuel in heating systems due to low price in Antalya province in the study area and this province has not geothermal energy [7,19]. The heating of modern greenhouses in Kütahya, Afyon, Aydın and Denizli provinces is provided by geothermal resources. The calculated findings related to fuel (coal and geothermal water) requirements and costs for plastic and polycarbonate greenhouses are presented in Table 6, 7, 8 and 9.

Table 6. The average coal requirement and costs per month for plastic greenhouse.

\begin{tabular}{ccccccccccc}
\hline \multirow{2}{*}{ Months } & \multicolumn{3}{c}{ Antalya } & \multicolumn{2}{c}{ Afyon } & \multicolumn{2}{c}{ Aydın } & \multicolumn{2}{c}{ Denizli } & \multicolumn{2}{c}{ Kütahya } \\
\cline { 2 - 12 } & t/ha & $\$ /$ ha & t/ha & $\$ /$ ha & t/ha & $\$ /$ ha & t/ha & $\$ /$ ha & t/ha & $\$ /$ ha \\
\hline Sep & - & - & 21.3 & 6625 & - & - & - & - & 27.1 & 8415 \\
Oct & - & - & 69.1 & 21,447 & 10.3 & 3203 & 19.4 & 6026 & 67.1 & 20,844 \\
Nov & 27.2 & 8432 & 113.7 & 35,300 & 45.7 & 14,179 & 59.9 & 18,596 & 104.7 & 32,507 \\
Dec & 58.5 & 18,173 & 158.7 & 49,276 & 77.1 & 23,941 & 93.9 & 29,164 & 149.8 & 46,504 \\
Jan & 70.4 & 21,869 & 174.6 & 54,203 & 89.7 & 27,865 & 107.6 & 33,402 & 166.9 & 51,841 \\
Feb & 55.9 & 17,361 & 140.7 & 43,696 & 71.4 & 22,183 & 86.7 & 26,937 & 135.3 & 42,024 \\
Mar & 44.0 & 13,667 & 114.2 & 35,452 & 58.1 & 18,036 & 69.2 & 21,500 & 118.4 & 36,781 \\
Apr & 16.0 & 4979 & 73.2 & 22,732 & 25.9 & 8056 & 32.0 & 9938 & 72.1 & 22,377 \\
May & - & - & 37.4 & 11,615 & - & - & - & - & 36.3 & 11,276 \\
June & - & - & 5.8 & 1798 & - & - & - & - & 10.6 & 3301 \\
\hline Annual & 272.1 & 84,481 & 908.6 & 282,145 & 378.3 & 117,464 & 468.8 & 145,562 & $888.4275,870$ \\
\hline
\end{tabular}

According to Table 6, the annual coal requirement values for plastic greenhouse ranged between 272.1 and $908.6 \mathrm{t} /$ ha depending on the heat requirements and heatingh time. Afyon province has the highest coal costs in respect to coal prices per unit $(282,145 \$ / \mathrm{ha})$ whereas Antalya $(84,481 \$ /$ ha) has the lowest coal costs.

Table 7. The average coal requirement and costs per month for polycarbonate greenhouse.

\begin{tabular}{|c|c|c|c|c|c|c|c|c|c|c|}
\hline \multirow{2}{*}{ Months } & \multicolumn{2}{|c|}{ Antalya } & \multicolumn{2}{|c|}{ Afyon } & \multicolumn{2}{|c|}{ Aydın } & \multicolumn{2}{|c|}{ Denizli } & \multicolumn{2}{|c|}{ Kütahya } \\
\hline & $\mathrm{t} / \mathrm{ha}$ & $\$ /$ ha & $\mathrm{t} / \mathrm{ha}$ & \$/ha & $\mathrm{t} / \mathrm{ha}$ & \$/ha & $\mathrm{t} / \mathrm{ha}$ & \$/ha & $\mathrm{t} / \mathrm{ha}$ & \$/ha \\
\hline Sep & - & - & 11.2 & 3464 & - & - & - & - & 14.2 & 4399 \\
\hline Oct & - & - & 36.1 & 11,212 & 5.4 & 1675 & 10.1 & 3150 & 35.1 & 10,897 \\
\hline Nov & 14.2 & 4408 & 59.4 & 18,455 & 23.9 & 7413 & 31.3 & 9722 & 54.7 & 16,994 \\
\hline Dec & 30.6 & 9501 & 83.0 & 25,761 & 40.3 & 12,516 & 49.1 & 15,247 & 78.3 & 24,312 \\
\hline Jan & 36.8 & 11,433 & 91.3 & 28,337 & 46.9 & 14,568 & 56.2 & 17,462 & 87.3 & 27,102 \\
\hline Feb & 29.2 & 9076 & 73.6 & 22,844 & 37.3 & 11,597 & 45.3 & 14,082 & 70.8 & 21,970 \\
\hline Mar & 23.0 & 7145 & 59.7 & 18,534 & 30.4 & 9429 & 36.2 & 11,240 & 61.9 & 19,228 \\
\hline Apr & 8.4 & 2603 & 38.3 & 11,884 & 13.6 & 4212 & 16.7 & 5196 & 37.7 & 11,699 \\
\hline May & - & - & 19.6 & 6072 & - & - & - & - & 19.0 & 5895 \\
\hline June & - & - & 3.0 & 940 & - & - & - & - & 5.6 & 1726 \\
\hline Annual & 142.2 & 44,166 & 475.0 & 147,502 & 197.8 & 61,409 & 245.1 & 76,099 & 464.4 & 144,222 \\
\hline
\end{tabular}

According to Table 7, the annual coal requirement values for polycarbonate greenhouse ranged between 142.2 and $475.0 \mathrm{t} / \mathrm{ha}$ depending on the heat requirements and heating time. Afyon province has the highest coal costs in respect to coal prices $(147,502 \$ /$ ha). Kütahya (144,222 \$/ha), Denizli (76,099 \$/ha), Aydın (61,409 \$/ha), Antalya (44,166 \$/ha) provinces are followed by Afyon Province. 
Table 8. The average geothermal water requirement and costs per month for plastis greenhouse.

\begin{tabular}{ccccccccc}
\hline \multirow{2}{*}{ Months } & \multicolumn{2}{c}{ Afyon } & \multicolumn{2}{c}{ Aydin } & \multicolumn{2}{c}{ Denizli } & \multicolumn{2}{c}{ Kütahya } \\
\cline { 2 - 9 } & $\mathrm{m}^{3} / \mathrm{ha}$ & $\$ / \mathrm{ha}$ & $\mathrm{m}^{3} / \mathrm{ha}$ & $\$ / \mathrm{ha}$ & $\mathrm{m}^{3} / \mathrm{ha}$ & $\$ / \mathrm{ha}$ & $\mathrm{m}^{3} / \mathrm{ha}$ & $\$ / \mathrm{ha}$ \\
\hline Sep & 6865 & 1204 & - & - & - & - & 8719 & 1530 \\
Oct & 22.222 & 3899 & 3319 & 582 & 6243 & 1095 & 21.597 & 3789 \\
Nov & 36.576 & 6417 & 14.692 & 2577 & 19.268 & 3380 & 33.682 & 5909 \\
Dec & 51.056 & 8957 & 24.806 & 4352 & 30.217 & 5301 & 48.184 & 8453 \\
Jan & 56.161 & 9853 & 28.872 & 5065 & 34.608 & 6072 & 53.714 & 9424 \\
Feb & 45.275 & 7943 & 22.985 & 4032 & 27.910 & 4896 & 43.542 & 7639 \\
Mar & 36.733 & 6444 & 18.688 & 3279 & 22.277 & 3908 & 38.109 & 6686 \\
Apr & 23.553 & 4132 & 8347 & 1464 & 10.297 & 1807 & 23.186 & 4068 \\
May & 12.035 & 2111 & - & - & - & - & 11.684 & 2050 \\
June & 1863 & 327 & - & - & - & - & 3420 & 600 \\
\hline Annual & 292.337 & 51,287 & 121.708 & 21,352 & 150.821 & 26,460 & 285.836 & 50,147 \\
\hline
\end{tabular}

According to Table 8, the annual geothermal water requirement values for plastic greenhouse in Afyon, Kütahya, Denizli, and Aydın provinces ranged between 121.708 and $292.337 \mathrm{~m}^{3} /$ ha depending on the heat requirements and heating time. Antalya province have not geothermal energy so geothermal water requirement of the greenhouses in this region was not calculated. Afyon province has the highest geothermal water costs $(51,287 \$ / \mathrm{ha})$ whereas Aydin $(21,352 \$ /$ ha $)$ has the lowest costs. It can be said that the geothermal energy reduces fuel costs of plastic greenhouse by $81.8 \%$ compared to coal costs (Table 6).

Table 9. The average geothermal water requirement and costs per month for polycarbonate greenhouse.

\begin{tabular}{ccccccccc}
\hline \multirow{2}{*}{ Months } & \multicolumn{2}{c}{ Afyon } & \multicolumn{2}{c}{ Aydin } & \multicolumn{2}{c}{ Denizli } & \multicolumn{2}{c}{ Kütahya } \\
\cline { 2 - 9 } & $\mathrm{m}^{3} / \mathrm{ha}$ & $\$ / \mathrm{ha}$ & $\mathrm{m}^{3} / \mathrm{ha}$ & $\$ / \mathrm{ha}$ & $\mathrm{m}^{3} / \mathrm{ha}$ & $\$ / \mathrm{ha}$ & $\mathrm{m}^{3} / \mathrm{ha}$ & $\$ / \mathrm{ha}$ \\
\hline Sep & 3589 & 630 & - & - & - & - & 4558 & 800 \\
Oct & 11.617 & 2038 & 1735 & 304 & 3264 & 573 & 11.291 & 1981 \\
Nov & 19.121 & 3355 & 7681 & 1347 & 10.073 & 1767 & 17.608 & 3089 \\
Dec & 26.691 & 4683 & 12.968 & 2275 & 15.797 & 2771 & 25.190 & 4419 \\
Jan & 29.360 & 5151 & 15.094 & 2648 & 18.093 & 3174 & 28.081 & 4927 \\
Feb & 23.669 & 4152 & 12.016 & 2108 & 14.591 & 2560 & 22.763 & 3994 \\
Mar & 19.203 & 3369 & 9770 & 1714 & 11.646 & 2043 & 19.923 & 3495 \\
Apr & 12.313 & 2160 & 4364 & 766 & 5383 & 944 & 12.121 & 2127 \\
May & 6292 & 1104 & - & - & - & - & 6108 & 1072 \\
June & 974 & 171 & - & - & - & - & 1788 & 314 \\
\hline Annual & 152.831 & 26,812 & 63.627 & 11,163 & 78.848 & 13,833 & 149.432 & 26,216 \\
\hline
\end{tabular}

According to Table 9, the annual geothermal water requirement values for polycarbonate greenhouse ranged between 63.627 and $152.831 \mathrm{~m}^{3} /$ ha depending on the heat requirements and heating time. It was observed that the annual geothermal water costs of polycarbonate greenhouse are between 11,163 and $26,812 \$ /$ ha. It can be said that the geothermal water costs were reduced by $47.7 \%$ compared to plastic greenhouse with geothermal energy (Table 8). 
In order to compare fuel requirement and cost in greenhouses, it is necessary to consider the amount of product obtained in the evaluations for healthier results. Tomato yields of 50 $\mathrm{kg} / \mathrm{m}^{2}$ in Kütahya, $34 \mathrm{~kg} / \mathrm{m}^{2}$ in Aydın, and $32 \mathrm{~kg} / \mathrm{m}^{2}$ in Antalya can be obtained from regularly heated greenhouses depending on the length of the production period [39].

According to the data of Table 6, when coal is used, the fuel cost for one $\mathrm{kg}$ of tomato production in Afyon, Kütahya, Aydın and Antalya provinces is $0.56 \$ / \mathrm{kg}, 0.55 \$ / \mathrm{kg}, 0.35$ $\$ / \mathrm{kg}$, and $0.26 \$ / \mathrm{kg}$, respectively. These values for polycarbonate greenhouse in Afyon, Kütahya, Aydın and Antalya provinces were $0.29 \$ / \mathrm{kg}, 0.28 \$ / \mathrm{kg}, 0.18 \$ / \mathrm{kg}$, and $0.14 \$ / \mathrm{kg}$, respectively (Table 7). When fossil energy sources are used in greenhouses, Afyon and Kütahya provinces can not compete with Antalya. However, it was determined that the polycarbonate greenhouses reduced fuel cost between 48.2 and $46.2 \%$.

According to the data of Table 8, when geothermal energy is used, the fuel cost for one $\mathrm{kg}$ of tomato production in Afyon and Kütahya, and Aydın provinces is $0.10 \$ / \mathrm{kg}$, and 0.06 $\$ / \mathrm{kg}$, respectively. These values for polycarbonate greenhouses in Afyon, Kütahya, and Aydın provinces were $0.054 \$ / \mathrm{kg}, 0.052 \$ / \mathrm{kg}$, and $0.033 \$ / \mathrm{kg}$, respectively (Table 9). The cost of production in the provinces where geothermal energy is available is more economical than fossil energy resources. It is also seen that polycarbonate greenhouses had a positive effect on this situation.

\section{Discussion}

Modern greenhouse production areas have continued to rise in Turkey in recent years and these greenhouse areas are especially increasing in the inner regions of the country. The main reason for this increase is the cheap heating provided by geothermal energy. For this reason, studies have started for the establishment of organized greenhouse zones in the provinces where geothermal energy is located.

Unlike the traditional greenhouses, these types of greenhouses are used for soilless growing and have automation systems. Heating process is carried out in accordance with the plant needs [7].

In this study, the heating requirements and costs were calculated for two model greenhouses having an area of approximately 1 ha at five different provinces. The maximum heating requirement was calculated for January at all provinces. When the annual heating requirement ranged between 6,096,283 $\mathrm{MJ} / \mathrm{ha}$ (for Antalya) and 20,359,946 MJ/ha (for Ayfon) for plastic greenhouses, this heating requirement ranged from 3,187,074 (for Antalya) to $10,643,972 \mathrm{MJ} / \mathrm{ha}$ (for Afyon) for the polycarbonate greenhouse. Polycarbonate greenhouse significantly reduced the heating requirement. This situation reflected the fuel costs. The coal costs for plastic greenhouse ranged between 84,481 $\$ /$ ha (for Antalya) and 282,145 $\$ /$ ha (for Ayfon) whereas these costs ranged from 44,166 $\$ /$ ha (for Antalya) to 147,502 $\$ /$ ha (for Afyon) for the polycarbonate greenhouse. The use of geothermal energy in greenhouse heating has reduced fuel costs by $81.8 \%$. The geothermal water costs for plastic greenhouse in Afyon, Kütahya, Denizli, and Aydın ranged between 21,352 \$/ha (for Aydın) and 51,287 \$/ha (for Ayfon) whereas these costs ranged from 11,163 $\$ /$ ha (for Aydin) to 26,812 \$/ha (for Afyon) for the polycarbonate greenhouse. The geothermal energy were reduced the fuel cost for one $\mathrm{kg}$ of tomato production in provinces where geothermal energy is available. For the province of Antalya, which has a significant potential in terms of greenhouse area, it can be said that the use of natural gas in greenhouse heating will reduce fuel costs. This will even increase the quantity and quality of the product received from the unit area. 


\section{Conclusion}

The limiting factors for crop production in greenhouses are in particular the outdoor temperature and the financial value of heating costs. Heating costs are one of the most important criteria that determine whether greenhouse cultivation can be made economically. These costs can be up to $60 \%$ of the total operating costs. Covering material is also important in reducing these costs. As a matter of fact, the cover material is effective on the internal microclimate of the greenhouse. In this study, it was determined that covering material had a significant effect on reducing these expenses. PC greenhouse cover material reduced heating requirement and fuel costs. Also, the use of geothermal energy in PC modern greenhouse heating has significantly affected reduced fuel costs.

Funding: This research received no external funding.

Conflict of Interest: The author declare that there are no conflicts of interest.

\section{References}

1. von Elsner, B.; Briassoulis, D.; Waaijenberg, D.; Mistriotis, A.; von Zabeltitz, C.; Gratraud, J.; Russo, G.; Suay-Cortes, R. Review of structural and functional characteristics in European Union countries, Part I: Design requirements. Journal of Agricultural Engineering Research 2000, 75(1), 1-16.

2. Tiwari, G.N. Greenhouse technology for controlled environment. Alpha Science International, Pangbourne, 2003.

3. Kendirli, B. Investigation of different approach for estimating greenhouse heating requirements. Süleyman Demirel Üniversity, Journal of The Faculty of Agriculture 2015, $10(2), 125-134$.

4. Fridleifsson, I.B. Status of geothermal energy amongst the world's energy sources. Geothermics 2003, 32, 379-388.

5. Sozen, A.; Arcaklioglu, E.; Ozkaymak, M. Turkey's net energy consumption. Applied Energy 2005, 81, 209-221.

6. Akdeniz, F.; Caglar, A.; Güllü, D. Recent energy investigations on fossil and alternative nonfossil resources in Turkey. Energy Conversion and Management 2002, 43, 575-589.

7. Canakci, M.; Emekli, N.Y.; Bilgin, S.; Caglayan, N. Heating requirement and its costs in greenhouse structures: A case study for Mediterranean region of Turkey. Renewable \& Sustainable Energy Reviews 2013, 24, 483-490.

8. Peker Say, N.; Yücel, M. Energy consumption and $\mathrm{CO}_{2}$ emissions in Turkey: Empirical analysis and future projection based on an economic growth. Energy Policy 2006, 34, 3870-3876.

9. Kaygusuz, K.; Kaygusuz, A. Geothermal energy in Turkey: The sustainable future. Renewable and Sustainable Energy Reviews 2004, 8, 545-563.

10. Ediger, V.S.; Kentel, E. Renewable energy potential as an alternative to fossil fuels in Turkey. Energy Conversion and Management 1999, 40, 743-755.

11. Lund, J.W.; Freeston, D.H.; Boyd, T.L. Direct application of geothermal energy: 2005 worldwide review. Geothermics 2005, 34, 691-727.

12. Baytorun, A.N. Comparison of fossil fuel and geotermal energy sources used for greenhouse heating. Turkish Journal of Agriculture-Food Science and Technology 2016,4(10), 832-839.

13. Gourdo, L.; Fatnassi, H.; Tiskatine, R.; Wifaya, A.; Demrati, H.; Aharoune, A.; Bouirden, L. Solar energy storing rock-bed to heat an agricultural greenhouse. Energy 2019, 169, 206-212. 
14. Hassanien, R.H.E.; Li, M.; Tang, Y. The evacuated tube solar collector assisted heat pump for heating. Energy and Buildings 2018, 169, 305-318.

15. Bazgaou, A.; Fatnassi, H.; Bouhroud, R.; Gourdo, L.; Ezzaeri, K.; Tiskatine, R.; Demrati, H.; Wifaya, A.; Bekkaoui, A.; Aharoune, A.; Bouirden, L. An experimental study on the effect of a rock-bed heating system on the microclimate and the crop development under canarian greenhouse. Solar Energy 2018, 176, 42-50.

16. Kasap, A.; Erdem, G.A. A research on determination of geothermal sourced heating system's advantages according to some other heating system in greenhouses covered by plastic and glass. In: Proceedings Symposium on Geothermal Applications Sept 27-30, Denizli, 1994.

17. Ozkan, B.; Celikyurt, M.A.; Karaguzel, O.; Akkaya, F. Production structure and main marketing problems of export oriented cut flower industry in Turkey. Acta Hortic 1997, 491, 481-487.

18. Anonymous. Greenhouse Sector, Protected cultivation. Mediterranean Exports Union Series, No: 60, Antalya, Turkey; 2009.

19. Emekli, N.Y.; Caglayan, N.; Ozmerzi, A.; Canakci, M. Structural Characteristics and Heat Requirements of Modern Greenhouses in southern of Turkey. Akdeniz Üniversity Journal of The Faculty of Agriculture 2012, 25(2), 93:101.

20. TUIK. Agricultural structure (production, price, value). Turkish Statistical Institute: Prime Ministry Press, 2018.

21. Yuksel, A.N. Greenhouse construction technique. Hasad Publication, Istanbul, Turkey; 2004.

22. Kacira, M.; Sase, S.; Kacira, O.; Okushima, L.; Ishii, M.; Kowata, H.; Moriyama, H. Status of greenhouse production in Turkey: Focusing on vegetable and floriculture production. Journal of Agricultural Meteorology 2004, 60, 115-122.

23. Titiz, K.S. Modern greenhouse cultivation. Publications of Antalya Industrialist's and Businessmen's Association, Antalya, Turkey,2004.

24. Kendirli, B.; Çakmak, B. Using of renewable energy sources in greenhouse heating. Journal of Environmental Sciences 2010, 2(1), 95-103.

25. Anonymous. Tenth development plan (20142018) Mining Policy Specialization Commission, Energy Raw Materials Group Geothermal Working Subgroup Report Ministry of Development, Ankara, 2013.

26. Canakci, M.; Akinci, I. The Comparison of modern and conventional farms in greenhouse vegetable cultivation of Antalya province. 24. Agricultural Mechanization Congress: 54-61, Kahramanmaras, Turkey; 2007.

27. Çolak, A. Greenhouse air conditioning and automation. Muğla Üniversitesi Publication no 31, Ortaca Meslek Yüksekokulu Publication no 01, Muğla, p.154, 2002.

28. Serpen, U.; Aksoy, N.; Öngür, T.; Korkmaz, E.D. Geothermal energy in Turkey: 2008 update. Geothermics 2009, 38, 227-237

29. Acarer, S. Design Principles of Greenhouse Heating Systems with Geothermal Energy. Geothermal Energy Seminar 115-127, İzmir, 2009.

30. Serpen, U.; Korkmaz, E.D.B.; Satman, A. Power generation potentials of majorgeothermal fields in Turkey. In: Proceedings of the 33rd Workshop on Geother-mal Reservoir Engineering, Stanford University, Stanford, CA, USA, p.134-139, 2008.

31. Anonymous. Greenhouse production recording system data Ministry of Food, Agriculture and Livestock, General Directorate of Crop Production, Ankara, 2015.

32. Anonymous. Turkish state meteorological service registrations Ankara, Turkey,2018.

33. Yağcioğlu, A. Greenhouse mechanization Ege Üniversity, Faculty of Agriculture, Publication No: 562, Izmir, Turkey, 2005. 
34. Karacabey, E. Determination of heat requirements of Greenhouses for some crops in Balcova (Izmir) and Examination of providing heat needed with different systems technically and economically. M.S. Thesis, Ege University, Izmir, Turkey; 2008.

35. Hakgoren, F.; Kürklü, A. Greenhouse planning. Akdeniz University, Faculty of Agricultural, Publication No: 6, Antalya, Turkey; 2003.

36. ANSI/ASAE EP 4063 MAR98 ASAE Standards Heating, Ventilating and Cooling Greenhouses; 1998

37. Öztürk, H.H. Greenhouse climatic technique. Hasad publications, Istanbul, Turkey; 2008.

38. Anonymous. Test reports of greenhouse heaters Akdeniz University, Faculty of Agriculture, Department of Agricultural Machinery, Antalya, Turkey, 2009b.

39. Zaimoglu, Z. Modeling of heat requirements for agricultural greenhouse in different climate regions Cukurova University. Journal of the Faculty of Engineering and Architecture 2017, 32(4):79-86 